\title{
Biyomedikal Uygulamalar için Wollastonit Partikül Takviyeli Hidroksiapatit Kompozit Granüllerin Üretilmesi ve Karakterizasyonu
}

\section{Production and Characterization of Wollastonite Particles Reinforced Hydroxyapatite Composite Granules for Biomedical Applications}

\author{
Fatih Erdem Baştan ${ }^{1 *}(0)$ Onurcan Karaarslan $2 \oplus$, Fatih Üstel ${ }^{3 \oplus}$ \\ 1,2,3 Sakarya University, Engineering Faculty, Department of Metallurgy and Materials Engineering, Thermal Spray \\ Research and Development Laboratory (SAU-TESLAB), 54187, Esentepe-Sakarya-Turkey \\ Sorumlu Yazar / Corresponding Author*: febastan@sakarya.edu.tr \\ Gelis Tarihi / Received: 09.01.2020 Araștırma Makalesi/Research Article \\ Kabul Tarihi / Accepted: 09.07.2020 DOI:10.21205/deufmd.2021236701 \\ Atıfșekli/How to cite BAŞTAN, F.E., KARAARSLAN, O., ÜSTEL, F.(2021). Biyomedikal Uygulamalar için Wollastonit Partikül Takviyeli \\ Hidroksiapatit Kompozit Granüllerin Üretilmesi ve Karakterizasyonu. DEUFMD, 23(67), 1-9.
}

Öz

Hidroksiapatit (HA) kemik ve dişin temel inorganik bileșenidir ve yüksek biyoaktiviteye, biyouyumluluğa ve kemik bütünleșim kabiliyetine sahiptir. Son zamanlarda, biyouyumluluk ve mekanik mukavemetini ileriye taşıyabilmek için HA yapısına wollastonitin (WT) takviye edilmesi önerilmektedir. Bu çalışmanın odak noktası, püskürtme kurutma ile HA/WT kompozit granüllerin üretilmesi ve karakterize edilmesidir. Ticari WT partikülleri, laboratuvar ortamında hazırlanan HA nanopartiküllerine katılarak, püskürtme kurutma çamuru hazırlanmıştır. Püskürtme kurutulan HA/WT granüllerinin (SD-HA/WT) termo-fiziksel özellikleri SEM, FTIR, granül boyut ölçümü, TGDTA ve XRD analizleriyle incelenmiştir. Analizler, kompozit granüllerin HA ve WT fazlarından oluștuğunu ortaya koymuștur. Granüller, matrisi olușturan HA nanopartiküllerden ve HA matris içerisine ve yüzeye karıșmış WT partiküllerden oluşmuştur. $750^{\circ} \mathrm{C}$ 'de yapılan ısıl işlem, sentezlenen HA nanopartiküllerin kalsinasyonuna neden olurken, $1000{ }^{\circ} \mathrm{C}$ ve $1250{ }^{\circ} \mathrm{C}$ 'de yapılan isıl işlemler sayesinde HA nanopartikülleri sinterlenmiștir, dolayısıyla granüllerin mekanik özellikleri artmıștır. Granüllerin faz yapıları ısıl işlemden sonra stabil kalmıştır (baskın olarak kristalin HA ve WT). Bununla birlikte, WT takviyesi HA'nın dehidroksilasyon sıcaklığının düşmesine neden olmuştur ve $1000{ }^{\circ} \mathrm{C}$ 'de yapılan ısıl işlemden sonra diğer kalsiyum fosfat fazları oluşmuştur. Rietveld Refinement analizi, granüllerin sırasıyla \%82,3 ve \%15,6 HA ve WT fazına sahip olduğunu ortaya çıkarmıştır. 36 $\mu \mathrm{m}$ medyan boyutuna (d50) sahip olan küresel granüller termal sprey, 3b yazıcı ve sıcak presleme prosesinde kullanılabilir.

Anahtar Kelimeler: Biyoseramikler, Püskürtme Kurutma, Kompozit, Hidroksiapatit, Wollastonit

\section{Abstract}

Hydroxyapatite (HA) is the main inorganic component of bone and teeth and having high bioactivity, biocompatibility and osteointegration capability. Recently, wollastonite (WT) has been offered to reinforce HA to further increase biocompatibility and also mechanical strength. The focus of this study 
DEÜ FMD 23(67), 1-9, 2021

was to produce and characterize HA/WT composite granules with spray drying. Commercial WT particles were introduced into the lab made HA nanoparticles in order to prepare a slurry for spray drying. Spray dried HA/WT granules (SD-HA/WT) were investigated in terms of thermo-physical properties by SEM, FTIR, granule size analyzer, TG-DTA and XRD. The investigations proved that composite granules were comprised both HA and WT phases. The granules contained HA nanoparticles (as a matrix) and WT particles that entangled in the HA matrix and on the surface of the granules. The heat treatment at $750{ }^{\circ} \mathrm{C}$ led to the calcination of synthesized HA nanoparticles, while, the nanoparticles were sintered together by the heat treatment at $1000{ }^{\circ} \mathrm{C}$ and $1250{ }^{\circ} \mathrm{C}$, thus the mechanical integrity of the granules was developed. The phase structure of the granules was remained stable (dominantly crystalline HA and WT) after the heat treatments. However, WT reinforcement caused to decrease the dehydroxylation temperature of $\mathrm{HA}$ and other calcium phosphates were formed after the heat treatment at $1000^{\circ} \mathrm{C}$. Rietveld Refinement analysis revealed that composite granules had $82.3 \%$ and $15.6 \%$ HA and WT phases, respectively. Spherical shaped granules with $36 \mu \mathrm{m}$ median size (d50) would be used in thermal spraying, 3d printing or hotpressing processes.

Keywords: Bioceramics, Spray Drying, Composite, Hydroxyapatite, Wollastonite

\section{Introduction}

HA performances in a pivotal role in bone grafting thanks to its osteoconductive nature, bone bonding ability and comparable chemical composition to that of natural bone causing no adverse effect on human body [1-3]. HA is used to produce bone repair materials, coatings, drug carriers for biomedical applications [4]. The in vivo dissolution rate of HA is under $10 \mathrm{wt}$ \% per year, which limits the bioresorbability of HA and its substitution with newly formed bone. Bioactivity and bioresorbability of a material are commonly acknowledged as the two critical properties for the third generation biomaterials [5]. Furthermore, the brittle nature and poor mechanical properties restrict HA to be used in load bearing applications [6].

Wollastonite (WT) is a strong candidate to be employed in biomedical applications owe to its non-toxicity, enhanced bioactivity, bioresorbability and mechanical stability.
Hydroxyapatite is formed relatively quicker on WT when immersed in simulated body fluid that develops the osteointegration of the material with the bone tissue $[7,8]$. For these reasons WT has been reinforced into the HA based materials to improve the bioresorption rate and mechanical properties [9].

Spray drying is a versatile tool to granulate HA nanoparticles for various applications as thermal spraying, cold-hot pressing and etc. In this process a ceramic slurry is atomized with a nozzle to droplets and the droplets are subsequently dried in a hot chamber. Finally, dried granules were collected in a chamber jar or a cyclone jar. Spray drying allows to produce granules having narrow size distribution with spherical, hollow and donut morphologies [10]. Not only, pure HA granules, but also ion substituted HA [11] and polymer modified HA granules [12] can be fabricated via spray drying. 


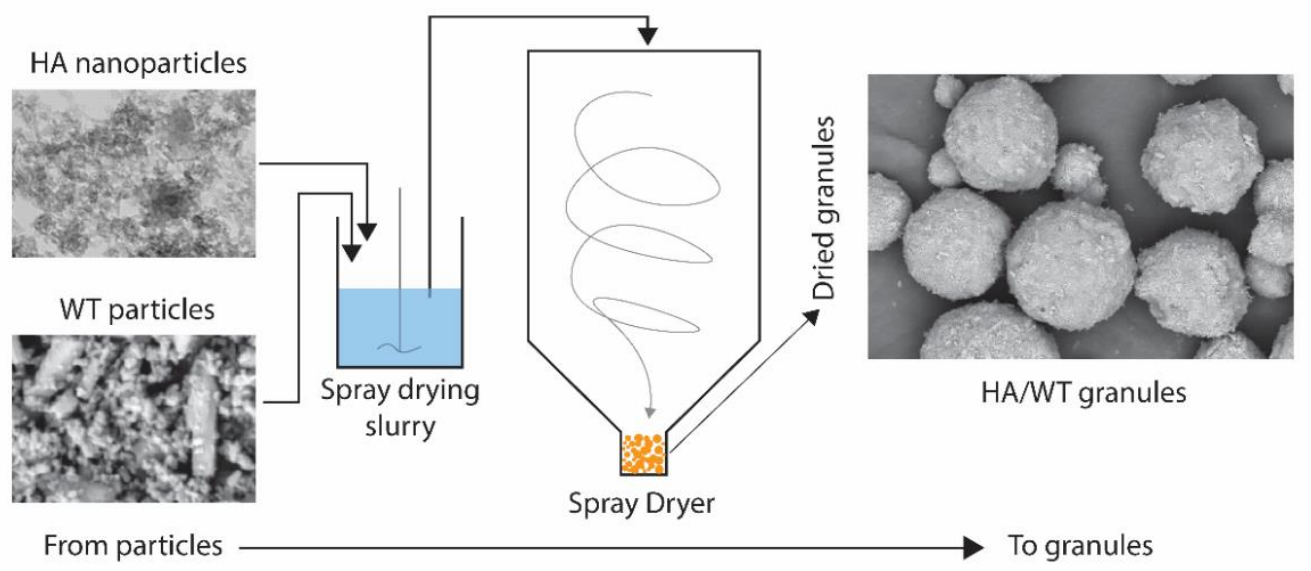

Figure 1. Schematic illustration of composite granules' producing process

In this study, we attempted to produce HA/WT composite granules via spray drying route. To calcine the synthesized HA nanoparticles and increase the mechanical integrity by sintering of the HA nanoparticles, the granules were heat treated at $750{ }^{\circ} \mathrm{C}, 1000{ }^{\circ} \mathrm{C}$ and $1250{ }^{\circ} \mathrm{C}$. Spray dried HA/WT granules (SD-HA/WT) were characterized with laser particle size analyzer, scanning electron microscopy, X-ray diffraction, TG-DTA and FTIR. The effect of the heat treatments on the granules were also studied.

\section{Material and Method}

HA nanoparticles were synthesized via wet chemical procedure. In summary, di-ammonium hydrogen phosphate (Merck, 98\%) aqueous solution was poured into calcium nitrate (Merck, 98\%) aqueous solution. Ca/P molar ratio was set at 1.67 and final suspension $\mathrm{pH}$ was adjusted via ammonia solution (Merck, 29\%) to 10.75. HA nanoparticles were precipitated for $24 \mathrm{~h}$ and filtered by Büchner funnel and washed with deionized water.

The production of the composite granules via spray drying is schematized in Figure 1. WT needle like particles (Alfa Aesar, $<20 \mu \mathrm{m}$ ) were grinded by a ball milling machine below $10 \mu \mathrm{m}$ and then mixed via HA wet cake in order to prepare the spray drying slurry. HA nanoparticles and grinded WT particles used for spray drying are presented in Figure 2. The solid content of the slurry was adjusted at $13 \mathrm{wt} \%$ with de-ionized water. Prepared slurry was peristaltically pumped into a two-fluid external nozzle with a $1.5 \mathrm{~mm}$ orifice. 1.5 bar pressurized air was used to atomize the slurry to the droplets. Atomized droplets were dried in the spray drying chamber (Nubilosa) and HA/WT granules were collected in the chamber jar. The inlet temperature and the velocity of hot air were selected as $215^{\circ} \mathrm{C}$ and $6.8 \mathrm{~m} / \mathrm{s}$, respectively.

The granules collected in the chamber jar were calcined and sintered at $750{ }^{\circ} \mathrm{C}, 1000{ }^{\circ} \mathrm{C}$ and $1250{ }^{\circ} \mathrm{C}$ to increase the mechanical integrity of the granules in an air furnace. The granule sizes were analyzed via laser particle size analyzer (Microtrac S3500). The surface and crosssection morphology of the granules were visualized via SEM (Tescan Vega II). Before SEM cross-section analyzes, the granules were embedded in an epoxy resin and grinded with SiC papers and then polished with cloths having $1 \mu \mathrm{m} \mathrm{Al}_{2} \mathrm{O}_{3}$ particles. The chemical bands and crystal structure of the granules were investigated with Fourier transform infrared spectroscopy (FTIR, Perkin Elmer) and X-ray diffraction analyzes (Rigaku D-max 2200), respectively. Thermogravimetric (TG) and differential thermal analysis (DTA) curves of the spray dried granules were investigated by Netzsch STA 449F1 (Pure HA granules produced via the same procedure were analyzed as a reference).

\section{Results and Discussion}

Figure 2 shows the initial particles used for spray drying to produce HA/WT composite granules. Synthesized HA particles had nano sizes below 
$20 \mathrm{~nm}$ and were highly agglomerated according to the TEM image (Figure 2A). WT needle like particles reduced smaller sizes by grinding procedure (below $10 \mu \mathrm{m}$ ) and presented smaller

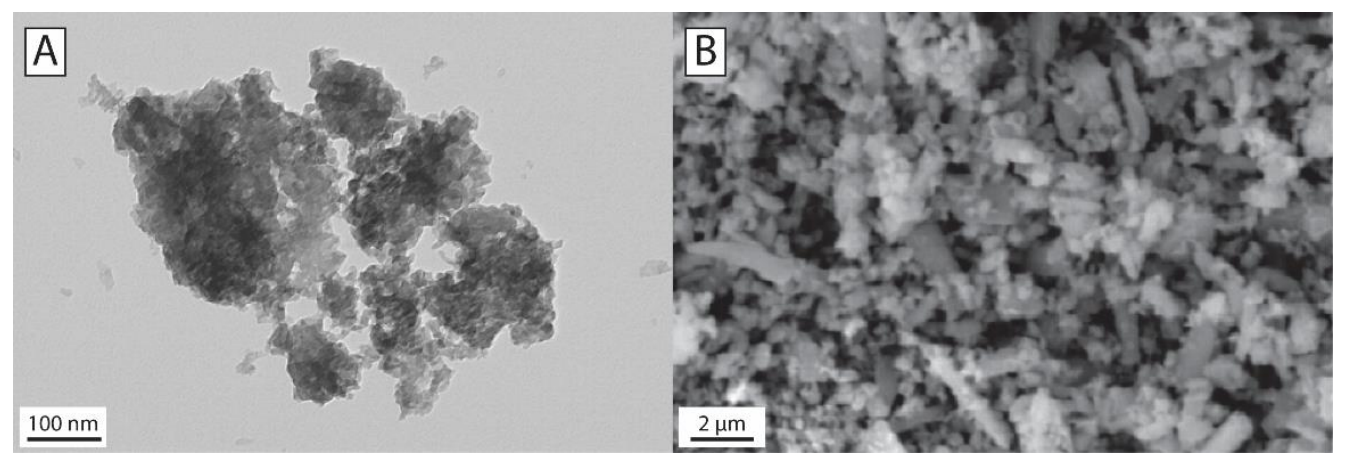

Figure 2. The initial particles for spray drying, A) HA nanoparticles and B) WT particles

Figure 3 demonstrates the SEM images of the SD$\mathrm{HA} / \mathrm{WT}$ composite granules calcined at $1000^{\circ} \mathrm{C}$. Spray dried HA/WT composite granules had spherical morphology (Figure 3A) and were composed of nano-HA particles (as the matrix) and reinforced WT particles (resided on the granules, Figure 3B). Metal-ceramic and ceramic-ceramic composite granules can easily be fabricated via spray drying. Wang et al. [13] prepared NiCoCrAlY- $\mathrm{Al}_{2} \mathrm{O}_{3}$ composite granules via spray drying. Lozano-Mandujano et al. [14] spray dried $\mathrm{La}_{2} \mathrm{Zr}_{2} \mathrm{O}_{7} / \mathrm{LaAlO}_{3}$ composite granules for thermal spraying applications. HA nano-particles were sintered together and coalesced through the thermal treatment process (Figure 3C). Thermal treatment allows to strengthen the granules via the sintering of the smaller particles within the granules [15].

Macro-porosities formed on the surface of the composite granules after sintering of the HA globular particles and relatively larger needle like particles illustrated in the SEM image (Figure 2B).

\begin{abstract}
nano-particles (Figure 3C). In our previous studies, we observed that spray dried nanostructured HA granules were sintered after the heat treatments at $1000{ }^{\circ} \mathrm{C}$ and $1250{ }^{\circ} \mathrm{C}$ and ultimately specific surface area and total pore volume of the granules were decreased and the granules were densified. However, in this study macro-porosities were remained after the sintering of the nano HA particles. Energy dispersive X-ray (EDX) mapping spectroscopy showed that SD-HA/WT granules involved $\mathrm{Ca}, \mathrm{P}$ and Si peaks that can be attributed to the HA and WT particles (Figure 3D). However, conclusive evidence should be needed to identify the crystal structure of the granules. WT particles were dispersed homogenously on the surface of the composite granules.
\end{abstract}




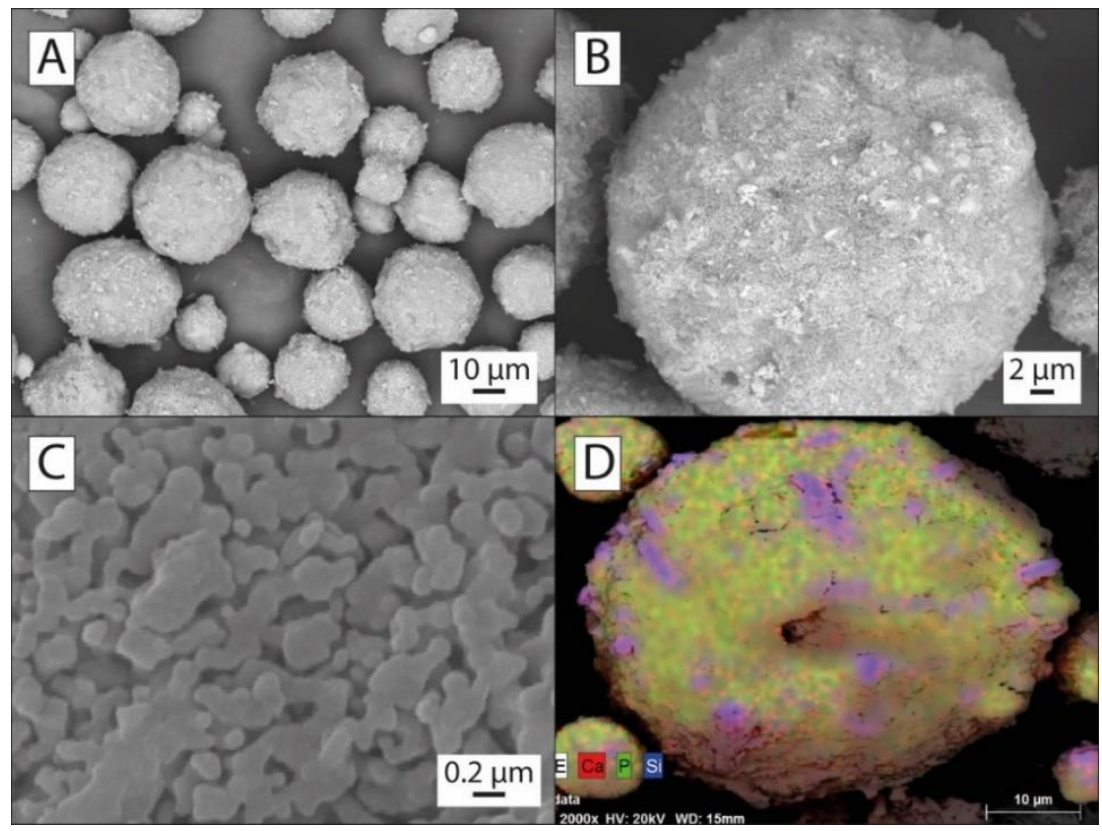

Figure 3. SEM surface images of spray dried HA/WT composite granules (A, B and C), EDX elemental mapping (D)

Figure 4 illustrates the cross-section SEM images of the composite granules. As spray dried HA/WT granules had solid cross section (Figure 4A). WT particles were non-agglomerated and dispersed homogenously throughout the cross section of the granules. Globular and needle like WT particles can be seen in the composite granules. Due to the higher surface energy, HA nanoparticles were agglomerated, and WT particles were entangled within the HA matrix. After the heat treatment at $1250{ }^{\circ} \mathrm{C}$, HA nanoparticles were sintered together and WT particles were retained within the granules (Figure 4B). Relatively higher amount of the larger sized porosities formed within the granules after the heat treatment as also investigated at the surface SEM analysis. The spherical morphology could contribute to the flowability of the granules [16] and could facilitate the handling and usage of the granules.

Figure 5 shows the size distribution of the spray dried and heat-treated composite granules. D10, D50 and D90 sizes of the granules were approximately $20 \mu \mathrm{m}, 36 \mu \mathrm{m}$ and $70 \mu \mathrm{m}$, respectively. Spray drying allows to produce granules with narrow size distributions [17], thus these granulated powders can be used in the special processes like thermal spraying.

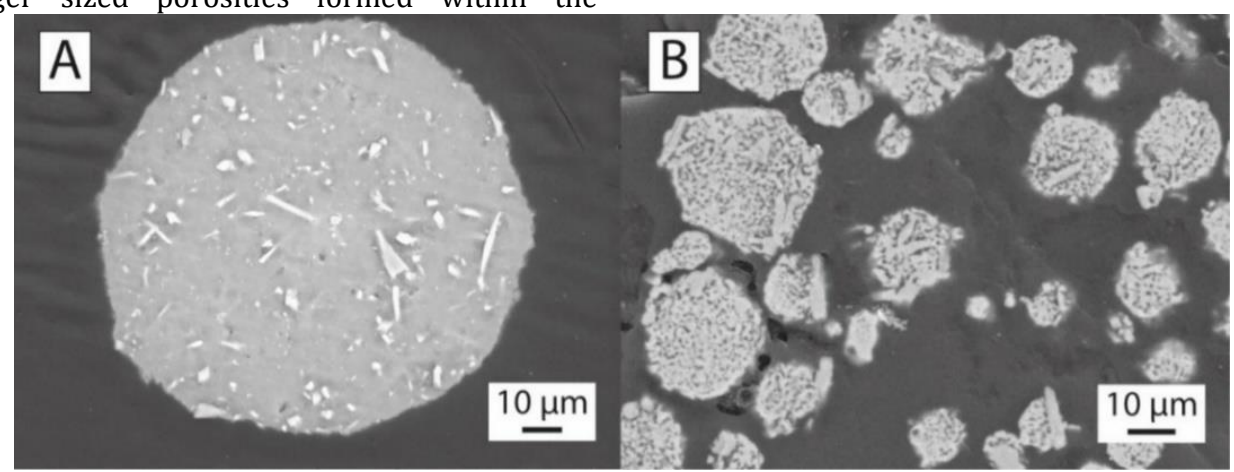

Figure 4. Cross-section SEM images of the granules, A) spray dried, B) heat treated at $1250{ }^{\circ} \mathrm{C}$ 
DEÜ FMD 23(67), 1-9, 2021

The granule size can be adjusted with the spray drying parameters such as; atomization pressure, inlet and outlet temperature, solid content, feed rate, and etc. The effect of calcination on the granule size of HA is multifold $[10,18,19]$ : Granule size can be decreased via the heat treatment due to the sintering of the nanoparticles within the granules and can be increased owing to the ballooning of the granules. Surprisingly, the granule size distributions remained identical after the heat treatments, in this study. This may occur due to the WT particles within the granules restricted the shrinkage of the granules. Consequently, macro porosities were formed in the granules after the sintering of the HA nanoparticles. This result was also consistent with the SEM images showing the macro-porous surface and cross section of the granules.

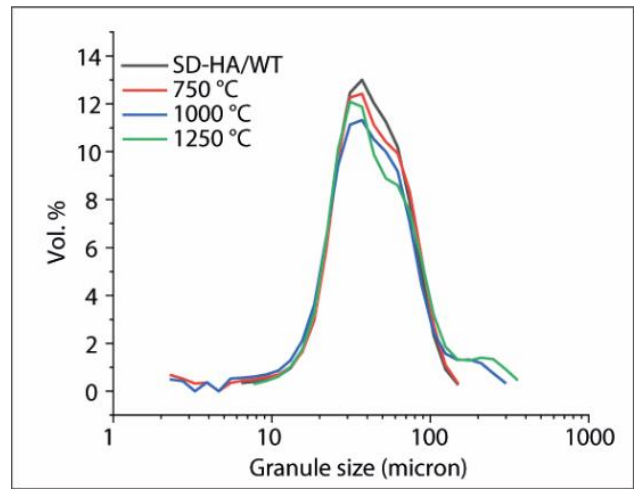

Figure 5. Granule size distribution of the spray dried and heat-treated granules

Figure 6 illustrates FTIR spectra of the spray dried and heat treated $\left(750{ }^{\circ} \mathrm{C}, 1000^{\circ} \mathrm{C}\right.$ and 1250 $\left.{ }^{\circ} \mathrm{C}\right) \mathrm{HA} / \mathrm{WT}$ granules. As spray dried HA/WT granules presented the characteristic phosphate and hydroxyl groups' FTIR bands of HA. The carbonate bands revealed that precipitated HA was non-stoichiometric and presented calcium deficient carbonated hydroxyapatite structure [20]. After the heat treatments the carbonate and water bands were vanished and only phosphate and hydroxyl bands were remained.

In addition to the FTIR bands of HA, the peak observed at around 900-950 $\mathrm{cm}^{-1}$ was assigned to the non-bridging oxygen bonds (NBO) of Si-ONBO [21]. FTIR results proved that composite granules contained both HA and WT phases. However, the reduce in the intensity of the hydroxyl peak at around $3570 \mathrm{~cm}^{-1}$ with the heat treatments could be assigned to the dehydroxylation of the HA structure. In this study this peak was almost disappeared after the heat treatment at $1000^{\circ} \mathrm{C}$ and $1250{ }^{\circ} \mathrm{C}$. It would be suggested that WT reinforcement to the HA granules caused early dehydroxylation of the HA crystal and thus HA structure may decompose to other calcium phosphates at lower temperatures.

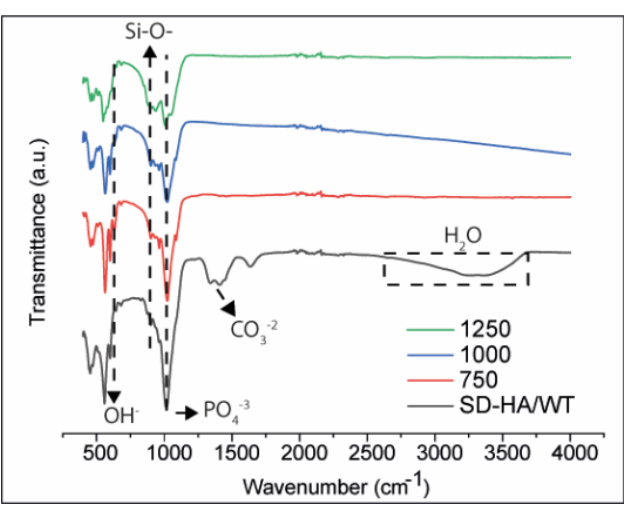

Figure 6. FTIR spectra of the spray dried and heat-treated granules

Figure 7 shows the TG and DTA curves of the pure HA and HA/WT composite granules. The thermal analyze of pure HA was described in detail in our previous study [10]. Pure HA and HA/WT granules lost 18.3 wt. $\%$ and 15.3 wt. \% up to $1000{ }^{\circ} \mathrm{C}$, respectively. Therefore, it may be suggested that HA/WT granules had 15 wt. \% WT particles when comparing the weight losses of the pure HA and HA/WT granules. This was identical to the value calculated at the Rietveld refinement analysis (Figure 9).

An endothermic peak was observed at $1040{ }^{\circ} \mathrm{C}$ in the DTA curve of HA/WT granules, whereas, this peak was beyond $1200{ }^{\circ} \mathrm{C}$ in the curve for pure HA. This peak was attributed to the dehydroxylation of the HA and therefore it can be concluded that WT particle reinforcement reduced the dehydroxylation temperature to the lower values, which means the decrease in the thermal stability of HA. This result was in accordance with the FTIR studies that showed reduce in the peak intensity of the hydroxyl group band at $\sim 3570 \mathrm{~cm}^{-1}$. 
DEÜ FMD 23(67), 1-9, 2021

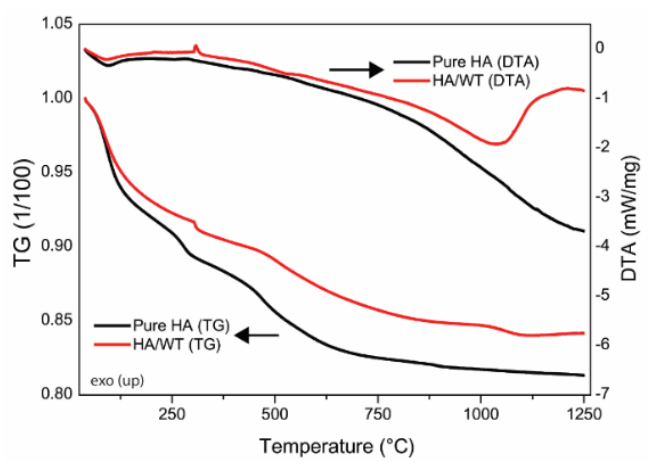

Figure 7. TG and DTA curves of spray dried pure HA and HA/WT granules.

Figure 8 demonstrates XRD spectrum of the spray dried and heat-treated HA/WT composite granules at $1000{ }^{\circ} \mathrm{C}$. XRD pattern was well matched with the standard diffraction peaks of both HA and WT crystal structure [22,23]. It was investigated that there was no clear effect of WT on the crystal structure of HA. The peaks at $2 \theta$ $31.7^{\circ}, 32.2^{\circ}$ and $33^{\circ}$ were attributed to the (211), (112) and (300) crystal planes of hydroxyapatite, respectively. The peaks at $2 \theta$ $29^{\circ}$ and $30^{\circ}$ can be assigned to the wollastonite phase. The sharp peaks implied the highly crystalline structure of the heat-treated composite granules.

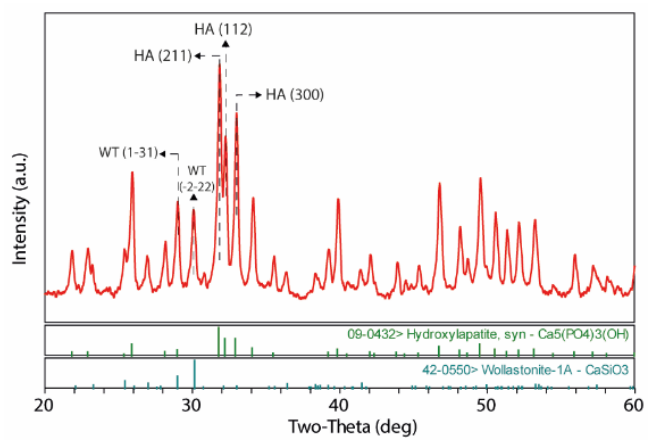

Figure 8. XRD pattern of spray dried and heattreated HA/WT granules at $1000^{\circ} \mathrm{C}$

In order to calculate the percentage of the hydroxyapatite and wollastonite phases within the composite granules Rietveld Refinement procedure was applied on the XRD pattern by Highscore Plus 4 software. Possible calcium phosphate and wollastonite phases were selected. The goodness of fit value (GOF) was below 1.5 after the refinement procedure. Figure 9 shows the Rietveld refinement results. Composite granules contained $82.3 \% \mathrm{HA}$ and $15.6 \%$ WT. Other minor decomposition phases of HA; tri-calcium phosphate $(1.7 \%)$ and tetracalcium phosphate $(0.3 \%)$ phases were also found. It may be concluded that due to the dehydroxylation of the HA by the WT reinforcement caused to decomposition of the HA phase at lower temperatures as also revealed by the thermal analysis and FTIR studies.

\section{Conclusion}

In this study, we produced wollastonite particles reinforced HA composite granules with spray drying and characterized the thermo-physical properties of the granules. Spray dried HA/WT had $36 \mu \mathrm{m}$ median granule size and spherical morphology. The granule sizes remained unchanged after the heat treatments, whereas, the porosity of the granules was increased. WT particles were entangled within the HA matrix. EDX, FTIR and XRD analyzes proved that composite particles were composed of both HA and WT phases. Rietveld Refinement analyzes showed that composite granules were composed of $\sim 15 \%$ WT phase. TG-DTA studies implied that WT reinforcement reduced the dehydroxylation peak temperature of HA. FTIR spectrum and XRD pattern of the composite granules were well matched with the hydroxyapatite and wollastonite. However, a slight decomposition of HA to the other calcium phosphates was also determined. Spherical morphology and narrow size distribution would facilitate composite granules to be used in thermal spraying, cold-hot pressing, $3 \mathrm{~d}$ printing etc. The high temperature behavior of the granules should further be analyzed for high temperature applications. The WT amount in the granules would be optimized according to the mechanical and biological properties of the products that fabricated from the composite granules. 


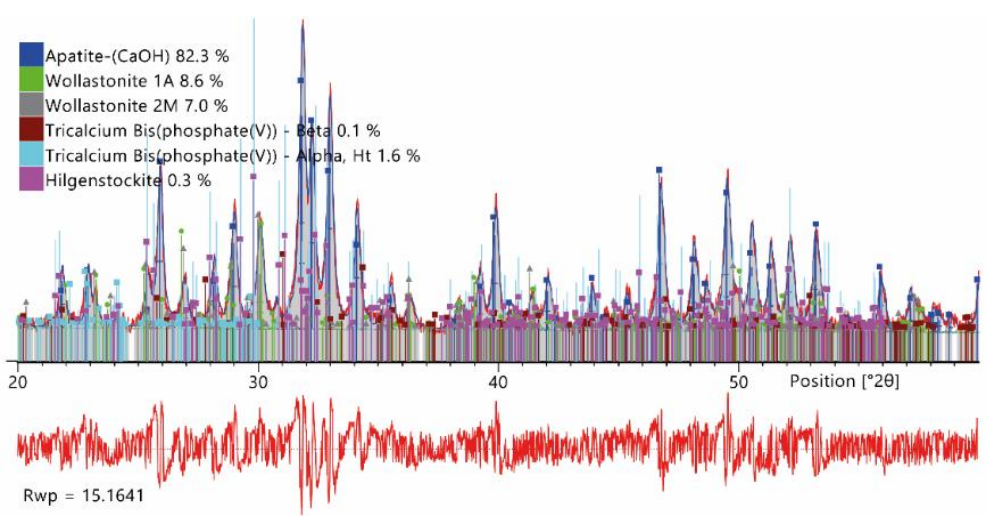

Figure 9. Observed pattern of HA-WT granules, calculated and difference XRD patterns after the Rietveld Refinement analysis

\section{Acknowledgement}

The authors would like to thank Sakarya University Department of Chemistry for the FTIR investigations and Research-Development Application and Research Center (SARGEM) of Sakarya University for the thermal analyzes.

\section{References}

[1] Siddiqui, H., Pickering, K., Mucalo, M., Siddiqui, H.A., Pickering, K.L., Mucalo, M.R. 2018. A Review on the Use of Hydroxyapatite-Carbonaceous Structure Composites in Bone Replacement Materials for Strengthening Purposes, Materials, vol. 11, pp. 1813. DOI: 10.3390/ma11101813.

[2] Yan, S., Feng, L., Zhu, Q., Yang, W., Lan, Y., Li, D., Liu, Y., Xue, W., Guo, R., Wu, G. 2018. Controlled Release of BMP-2 from a Heparin-Conjugated StrontiumSubstituted Nanohydroxyapatite/Silk Fibroin Scaffold for Bone Regeneration, ACS Biomaterials Science \& Engineering, vol. 4, pp. 3291-3303. DOI: 10.1021/acsbiomaterials.8b00459.

[3] Wang, Q., Tang, P., Ge, X., Li, P., Lv, C., Wang, M., Wang, K., Fang, L., Lu, X. 2018. Experimental and simulation studies of strontium/zinc-codoped hydroxyapatite porous scaffolds with excellent osteoinductivity and antibacterial activity, Applied Surface Science, vol. 462, pp. 118-126. DOI: 10.1016/j.apsusc.2018.08.068.

[4] Wei, L., Yang, H., Hong, J., He, Z., Deng, C. 2019 Synthesis and structure properties of Se and Sr codoped hydroxyapatite and their biocompatibility, Journal of Materials Science, vol. 54, pp. 25142525. DOI: $10.1007 /$ s10853-018-2951-7.

[5] Zhu, H., Guo, D., Sun, L., Li, H., Hanaor, D.A.H., Schmidt, F., Xu, K. 2018. Nanostructural insights into the dissolution behavior of Sr-doped hydroxyapatite, Journal of the European Ceramic Society, vol. 38, pp. 5554-5562. DOI: 10.1016/j.jeurceramsoc.2018.07.056.
[6] Yao, H.-L., Hu, X.-Z., Bai, X.-B., Wang, H.-T., Chen, Q.Y., Ji, G.-C. 2018. Comparative study of HA/TiO2 and $\mathrm{HA} / \mathrm{ZrO} 2$ composite coatings deposited by high-velocity suspension flame spray (HVSFS), Surface and Coatings Technology, vol. 351, pp. 177-187. DOI: 10.1016/j.surfcoat.2018.07.082.

[7] Garcia, E., Miranzo, P., Sainz, M.A. 2018. Thermally sprayed wollastonite and wollastonite-diopside compositions as new modulated bioactive coatings for metal implants, Ceramics International, vol. 44, pp. 12896-12904. DOI: 10.1016/j.ceramint.2018.04.100.

[8] R. Morsy 2016. Synthesis and in vitro Bioactivity Mechanism of Synthetic $\alpha$-wollastonite and $\beta$ wollastonite Bioceramics,. DOI: 10.4416/JCST2015-00028.

[9] Solonenko, A.P., Blesman, A.I., Polonyankin, D.A. 2018. Preparation and in vitro apatite-forming ability of hydroxyapatite and $\beta$-wollastonite composite materials, Ceramics International, vol. 44, pp. 17824-17834. DOI: 10.1016/j.ceramint.2018.06.251.

[10] Bastan, F.E., Erdogan, G., Moskalewicz, T., Ustel, F. 2017. Spray drying of hydroxyapatite powders: The effect of spray drying parameters and heat treatment on the particle size and morphology, Journal of Alloys and Compounds, vol. 724, pp. 586-596. DOI: 10.1016/j.jallcom.2017.07.116.

[11] Özbek, Y.Y., Baştan, F.E., Üstel, F. 2016. Synthesis and characterization of strontium-doped hydroxyapatite for biomedical applications, Journal of Thermal Analysis and Calorimetry, vol. 125 , pp. $745-750$. DOI: $10.1007 /$ s10973-0165607-3.

[12] Ben, Y., Zhang, L., Wei, S., Zhou, T., Li, Z., Yang, H., Wang, Y., Selim, F.A., Wong, C., Chen, H. 2017. PVB modified spherical granules of $\beta$-TCP by spray drying for 3D ceramic printing, Journal of Alloys and Compounds, vol. 721, pp. 312-319. DOI: 10.1016/j.jallcom.2017.06.022. 


\section{DEÜ FMD 23(67), 1-9, 2021}

[13] Wang, H., Liu, Y., Ning, X., Wang, Q., Wang, F., Chen, D. 2017. The influence of milling parameters on the characteristics of milled and spray-dried NiCoCrAlY-Al2O3 composite powders, Powder Metallurgy, vol. 60, pp. 15-21. DOI: 10.1080/00325899.2016.1264683.

[14] Lozano-Mandujano, D., Poblano-Salas, C.A., RuizLuna, H., Esparza-Esparza, B., Giraldo-Betancur, A.L., Alvarado-Orozco, J.M., Trápaga-Martínez, L.G., Muñoz-Saldaña, J. 2017. Thermal Spray Deposition, Phase Stability and Mechanical Properties

La $<$ Subscript $>2<$ /Subscript $>\mathrm{Zr}<$ Subscript $>2</$ Su bscript $>0<$ Subscript $>7</$ Subscript $>/$ LaAlO $<$ Subs cript $>3<$ /Subscript $>$ Coatings, Journal of Thermal Spray Technology, vol. 26, pp. 1198-1206. DOI: 10.1007/s11666-017-0569-y.

[15] Sánchez, E., Moreno, A., Vicent, M., Salvador, M.D. Bonache, V., Klyatskina, E., Santacruz, I., Moreno, R 2010. Preparation and spray drying of Al203TiO2 nanoparticle suspensions to obtain nanostructured coatings by APS, Surface and Coatings Technology, vol. 205, pp. 987-992. DOI: 10.1016/j.surfcoat.2010.06.002.

[16] Bertrand, G., Roy, P., Filiatre, C., Coddet, C. 2005 Spray-dried ceramic powders: A quantitative correlation between slurry characteristics and shapes of the granules, Chemical Engineering Science, vol. 60, pp. 95-102. DOI: 10.1016/j.ces.2004.04.042.

[17] Schrijnemakers, A., André, S., Lumay, G., Vandewalle, N., Boschini, F., Cloots, R., Vertruyen, B. 2009. Mullite coatings on ceramic substrates: Stabilisation of Al203-SiO2 suspensions for spray drying of composite granules suitable for reactive plasma spraying, Journal of the European Ceramic Society, vol. 29, pp. 2169-2175. DOI: 10.1016/j.jeurceramsoc.2009.01.031.

[18] Patel, N., Gibson, I.R., Ke, S., Best, S.M., Bonfield, W. 2001. Calcining influence on the powder properties of hydroxyapatite, Journal of Materials Science: Materials in Medicine, vol. 12, pp. 181188. DOI: $10.1023 / \mathrm{A}: 1008986430940$.

[19] Wang, A.-J., Lu, Y.-P., Zhu, R.-F., Li, S.-T., Xiao, G.-Y., Zhao, G.-F., Xu, W.-H. 2008. Effect of sintering on porosity, phase, and surface morphology of spray dried hydroxyapatite microspheres, Journal of Biomedical Materials Research Part A, vol. 87A, pp. 557-562. DOI: 10.1002/jbm.a.31895.

[20] Baștan, F.E., Atiq Ur Rehman, M., Avcu, Y.Y., Avcu, E., Üstel, F., Boccaccini, A.R. 2018. Electrophoretic co-deposition of PEEK-hydroxyapatite composite coatings for biomedical applications, Colloids and Surfaces B: Biointerfaces, vol. 169, pp. 176-182. DOI: 10.1016/j.colsurfb.2018.05.005.

[21] Palakurthy, S., P, A.A., K, V.R. 2019. In vitro evaluation of silver doped wollastonite synthesized from natural waste for biomedical applications, Ceramics International, . DOI: 10.1016/j.ceramint.2019.03.169.
[22] Zhao, S.-N., Yang, D.-L., Wang, D., Pu, Y., Le, Y., Wang, J.-X., Chen, J.-F. 2019. Design and efficient fabrication of micro-sized clusters of hydroxyapatite nanorods for dental resin composites, Journal of Materials Science, vol. 54, pp. 3878-3892. DOI: $10.1007 / s 10853-018-3125-$ 3.

[23] Chen, Z., Zhai, J., Wang, D., Chen, C. 2018. Bioactivity of hydroxyapatite/wollastonite composite films deposited by pulsed laser, Ceramics International, vol. 44, pp. 10204-10209. DOI: 10.1016/j.ceramint.2018.03.013. 